\title{
Male and Female Speech in Pride and Prejudice Novel by Jane Austen and Its Implication in Teaching Speaking
}

\author{
Nuria Dhotul Janah ${ }^{1}$ \\ ${ }^{1}$ UIN Walisongo Semarang \\ ${ }^{1}$ hea.cute93@gmail.com \\ Siti Tarwiyah ${ }^{2}$ \\ ${ }^{2}$ UIN Walisongo Semarang \\ 2 sititarwiyah98@gmail.com
}

\begin{abstract}
The study of gender is essential to the study of language. It is quite clear that male and female characters are different in many aspects. They not only different in their physical aspect but also in using a language. This research aimed to uncover the differences of a linguistic feature in the speech of male and female characters based on woman's language theory revealed by Robin Tolmach Lakoff, linguistic features which are dominantly used by male and female characters and its implication in teaching speaking. Lakoff is a linguist who began the research of the feature of woman's language. The data of this research were taken from conversations of male and female main characters in Pride and Prejudice novel by Jane Austen. Data collection technique used was documentation which was applied two steps they are reading the novel thoroughly and enlisting all speeches uttered by the main characters of the novel. The instrument of this research was Documentation Guideline. The researcher analyzed the data by using analysis technique according to Mile and Huberman, namely data reduction, data display, and verification. This research revealed that male and female character differs in their number of using of linguistic features. Female characters are stated use more lexical hedge, avoidance of strong swear word, rising intonation on declarative, empty adjective, intensifier, emphatic stress and super polite form than male do. Female characters use those features to show their uncertainty toward things; they tend to avoid strong swear word and use more superpolite form. Therefore, female expressions are considered more polite than male. Consequently, they can avoid friction in their conversation and build effective communication across gender. This result is in line with Lakoff theory. The researcher found that the feature which is dominantly used by male and female is an intensifier. Furthermore, the implication of this research in teaching speaking especially complimenting and interrupting expression as the functional expression is the student needs to exposed expressions of complimenting and interrupting appropriately.
\end{abstract}

\section{ARTICLE HISTORY}

Received 19 April 2017

Accepted 9 September 2017

\section{KEYWORDS}

gender differences; linguistic feature; speaking

\section{Introduction}

In this world, we were created as human. God created human into two parts: male, and female. That is the basic aspect of human commonly; sex differences or human differences are usually known. Fakih says that sex differences are used by 
people when they talked about men and women by discovering matters dealing with biological characteristics like genital and anatomy physically. Furthermore, the biological characteristics give involve any aspects for human-like politeness, strata social, and language learning. On the other hand, gender differences are used by people when they talked about psychologically emotional and mental characteristics (see Mansour Fakih, 1996:08).

In life, human being needs a medium to interact with other people. The medium used by human being is called language. Language has an important function to all societies who used it because language is a way to interact one to another person, especially in communication. Through language, a human being can understand each other, and the speakers can identify themselves as well as they view their language as a symbol of their identity (see Djoko Kenthjono, 2003:02). So, it can be said that a language is a communication tool which important for a human being to convey messages or information and used to interact with others.

People around us belong to variety of social types. People have a different way to express something. According to Lakoff, women and men speak English in different ways. They have been taught to speak differently since young, girls should speak in a passive voice and boys should speak what is termed rough talk or active voice. In this regard, women frequently use women language. According to Lakoff in Holmes book, ten speeches characterized women linguistic features: lexical hedge, empty adjective, precise color term, avoidance of strong swear word, intensifier, rising intonation on declarative, hypercorrect grammar, tag question, emphatic stress, and super polite form. But in this study, the researcher did not examine hypercorrect grammar because in this data almost the conversation used of the standard verb form both male and female. Lakoff believes that the use of tag questions by women is the sign of uncertainty. This study is not in line with the study conducted by Holmes. He found out that certain types of tag question are used more by men than by women.

Many factors cause male and female differences in language use. According to Cameron and Coates, the amount we talk about is influenced by who we are with and what we are doing. They also add that if we aggregate a large number of studies, it will be observed that there is little difference between the amount men and women talk. Furthermore, Lakoff said that gender differences in language use reflect different and unequal roles and status because of the lower status of women in society they are pressured to talk like a lady.

To be a good speaker, the ability to produce utterance is not enough. There is much linguistics to be mastered by languages learners in order to be able to express their feelings, and ideas appropriately. Therefore study is made to identify the differences of linguistic features in male and female characters in Pride and Prejudice novel and linguistic feature which is dominantly used by male and female characters and to find out the implication of this study in teaching speaking especially complimenting and interrupting expressions. The data are taken from a 
conversation between male and female main characters of Pride and Prejudice novel because this novel is one of the most popular novels in English Literature and listed as "most loved book."

\section{Methods}

The type of this research is library research, and the researcher used the descriptive qualitative method. Research by using descriptive qualitative is the research that is aimed at arranging a description of the situation or events. This method used in this research was intended to describe the gender differences of male and female speech in Pride and Prejudice novel by Jane Austen based on linguistic feature proposed by Lakoff. Descriptive qualitative is a research method that aims to describe fully and deeply about social reality and some phenomena that occur in the community that is the subject of research so indescribable traits, characteristics and models of the phenomenon (see Wina Sanjaya, 2013:47). The primary source of this research was a novel entitled Pride and Prejudice. The author of this novel is Jane Austen, and it published in 1813. The focus of this research was the difference of linguistic features of male and female speech that uttered by the main characters of Pride and Prejudice novel. This research examined the differences of linguistic features listed by Lakoff. The data collection technique for this research established by using documentation. In recent research, the data taken from utterances from the main characters of Pride and Prejudice novel such as such as Elizabeth Bennet, Jane Bennet, Mr. Bingley, and Mr. Darcy because they have an important role in this novel. In collecting the data, the researcher used the following steps: read the novel thoroughly and enlist all speeches uttered by the main characters of the novel.

This research used Documentation Guideline as the instrument because this research applied documentation as the technique of data collection. Suharsimi Arikunto research instrument is a tool or facility used by the researcher to collect the data so that easier to do, have a better result, complete and systematic, as a result, will be easier to be processed.

An analysis used in this research is an analysis according to Miles and Huberman in Afrizal. Activities in data analysis technique are conducted interactively and continuously until complete so that the data are already saturated. The interactive model is as follow: 


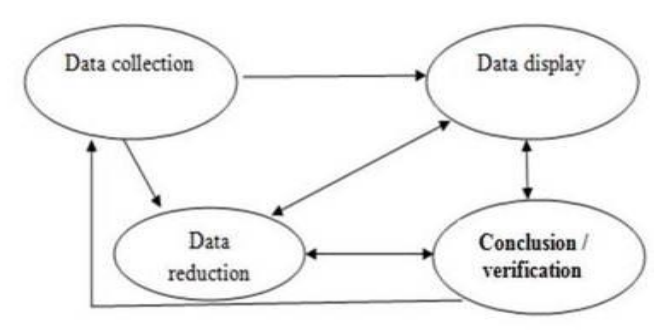

Figure 1.1 The Components of Data Analysis according to Miles and Huberman

\section{Result and Discussion}

The differences of linguistic features in the speech of male and female in Pride and Prejudice novel by Jane Austen

Gender differences in language use reflect the different and unequal role and status. Female pressured to talk like a lady because they have lower status in society. (see Lakoff Robin, 1975:52) The study of gender is important to the study of language. It is quite clear that male and female differences in any aspects mainly in language use. Before conveying the differences between male and female based on linguistic feature listed by Lakoff, it is better to display the quantity of linguistic feature uttered by male and female main characters in Pride and Prejudice novel in order to get a clear explanation about it.

Table 1.1 The Quantity of linguistic feature uttered by male main characters in Pride and Prejudice novel

\begin{tabular}{llll}
\hline No. & Linguistic Feature & Male speech & Percentage \\
\hline 1 & Lexical hedge & 5 & $11.363 \%$ \\
\hline 2 & Empty adjective & 1 & $2.273 \%$ \\
\hline 3 & $\begin{array}{l}\text { Avoidance of } \\
\text { strong swear word }\end{array}$ & 0 & $0 \%$ \\
\hline 4 & Precise color term & 0 & $0 \%$ \\
\hline 5 & $\begin{array}{l}\text { Rising intonation } \\
\text { on declarative }\end{array}$ & 1 & $2.273 \%$ \\
\hline 6 & Intensifier & 31 & $70.455 \%$ \\
\hline 7 & Emphatic stress & 0 & $0 \%$ \\
\hline 8 & Tag question & 1 & $2.273 \%$ \\
\hline 9 & Super polite form & 5 & $11.363 \%$ \\
\hline Total & $\mathbf{4 4}$ & $\mathbf{1 0 0 \%}$ \\
\hline
\end{tabular}


Table 1.2 The quantity of linguistic feature uttered by female main characters in Pride and Prejudice novel

\begin{tabular}{llll}
\hline No. & Linguistic Feature & Female speech & Percentage \\
\hline 1 & Lexical hedge & 35 & $18.618 \%$ \\
\hline 2 & Empty adjective & 5 & $2.659 \%$ \\
\hline 3 & $\begin{array}{l}\text { Avoidance of } \\
\text { strong swear word }\end{array}$ & 31 & $16.489 \%$ \\
\hline 4 & Precise color term & 0 & $0 \%$ \\
\hline 5 & $\begin{array}{l}\text { Rising intonation } \\
\text { on declarative }\end{array}$ & 12 & $6.383 \%$ \\
\hline 6 & Intensifier & 88 & $46.809 \%$ \\
\hline 7 & Emphatic stress & 9 & $4.788 \%$ \\
\hline 8 & Tag question & 1 & $0.531 \%$ \\
\hline 9 & Super polite form & 7 & $3.723 \%$ \\
\hline Total & & $\mathbf{1 8 8}$ & $\mathbf{1 0 0 \%}$ \\
\hline
\end{tabular}

Language reflects, records, and transmits social differences, so we should not be surprised to find reflections of gender differences in language, for most societies differentiate between men and women in various marked ways. The tables above represent some linguistic features listed by Lakoff that found in a conversation between male and male main characters in Pride and Prejudice novel. Therefore, the differences of a linguistic feature in the speech of male and female as follows:

1. Lexical hedge

There were five kinds of lexical hedges uttered by male and female of main characters in Pride and Prejudice novel such as you know, well, suppose, I think, or I thought, and perhaps. However, male characters only uttered two kinds of them. Namely, $i$ think, and you know, whereas female characters used all the kinds of lexical hedges above. Those features used to express uncertainty or lack selfconfidence. For example:

a. "I think I have heard you say that their uncle is an attorney on Meryton."

b. "Perhaps I did not always love him so well as I do now."

Besides, the lexical hedges also used by them to strengthen their assertions.

For example:

a. "You know how I detest it unless I am particularly acquainted with my partner." 
b. "Come, Mr. Wickham, we are brother and sister, you know.

2. Empty adjective

Empty adjective conveys an emotional reaction than specific information, and it showed that female more expressive. In this research, the empty adjective was uttered by male and female characters to show their approbation or admiration to things. For example:

a. "What a charming amusement for young people this is, Mr. Darcy!

3. Avoidance of strong swear word

Swear words are kinds of interjection that can express extreme intensify. Female characters avoided a strong swear word by using a word like dear, but male characters did not use swear word in this data.

For example:

a. "What do you think of this sentence, my dear Lizzy?"

b. Good Heaven!

4. Precise color term

Women make far more precise discrimination of color than men. The words like mauve, lavender, beige, aquamarine, etc. Surprisingly, in this research both male and female characters did not use these words.

5. Rising intonation on declarative

Rising intonation on declarative was uttered only by female characters. It was aimed to seek information, or the speaker may want to get the requisite information. For example:

a. "You persist, then, in supposing his sisters influence him?"

b. "You mean to frighten me, Mr. Darcy, by coming in all this state to hear me?

6. Intensifier

Intensifier also one of linguistic feature listed by Lakoff. It was uttered by both male and female characters, and it used to strengthen their assertion and also used to stress their emotion. There were five kinds of intensifier were used in this data such as so, too, do, very and quite. For example:

a. "This seems a very comfortable house."

b. It is really too distressing."

7. Emphatic stress

Emphatic stress is linguistic feature that used to strengthen the statement. Besides, it also used to express uncertainty about what asserted. It was uttered by both male and female characters.

a. "What a charming amusement for young people this is, $\mathrm{Mr}$. Darcy!"

b. "It is every way horrible!"

8. Tag question

The tag question is the syntactic shape (in English) is midway between an 
obvious statement and a yes-no question it used to express uncertainty meaning or express affective meaning. It uttered by male and female characters of Pride and Prejudice novel.

9. Super polite form

The super polite form can be exemplified become indirect request and euphemism. Super polite form is uttered to make the listeners feel comfortable and to hold on well the relationship.

a. "I am sorry, exceedingly sorry," replied Darcy, in a tone of surprise and emotion, "that you have ever been informed of what may, in a mistaken light, have given you uneasiness."

b. "Thank you, sir, but a less agreeable man would satisfy me."

Based on the data, the researcher found the gender differences of linguistic feature used by male and female in the speech of main characters of Pride and Prejudice novel. The differences found based on the woman's language theory. It can be described as follows: first, female characters used lexical hedge more than male do, it proved by the amount of female speech which can be seen in the appendix. In this case, it showed that female characters felt more unconfident than male because they used lexical hedges like well, I think, perhaps and so on. Therefore, female characters could avoid friction when they were talking to others.

Second, female and male characters are different in choosing vocabulary like when they mentioned adjective and swear word. Female has a specific empty adjective that used to show their approbation and admiration for things. Meanwhile, male tend to choose a neutral adjective like great, cool, terrific and so on. Furthermore, female characters tend to avoid of strong swear word, and it showed that female choose a word like dear. However, in this data, male characters did not use swear word.

\section{A linguistic feature which is dominantly used by male and female}

Before determining the linguistic feature which is dominantly used by male and female characters, it would be better if the researcher displays a diagram.

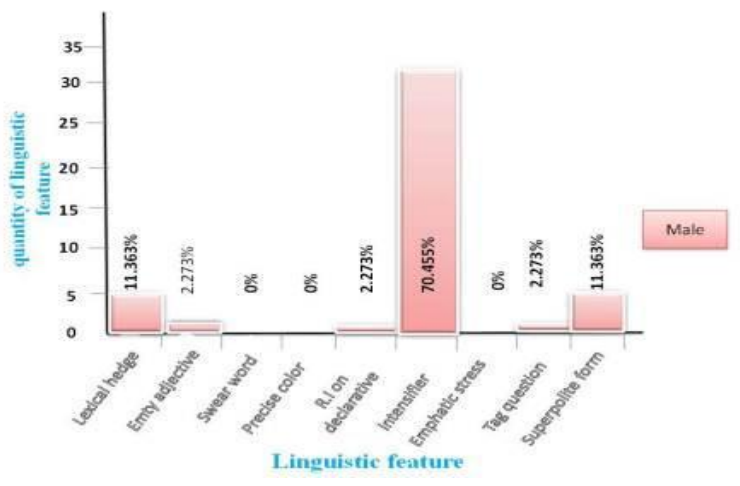


Diagram 2.1 Representative of the Frequency of Male Linguistic Feature From the diagram above it showed that male characters used more intensifier than other features. It used to strengthen his statement. The features that male did not use in this data is avoidance of strong swear words, precise color term, and emphatic stress.

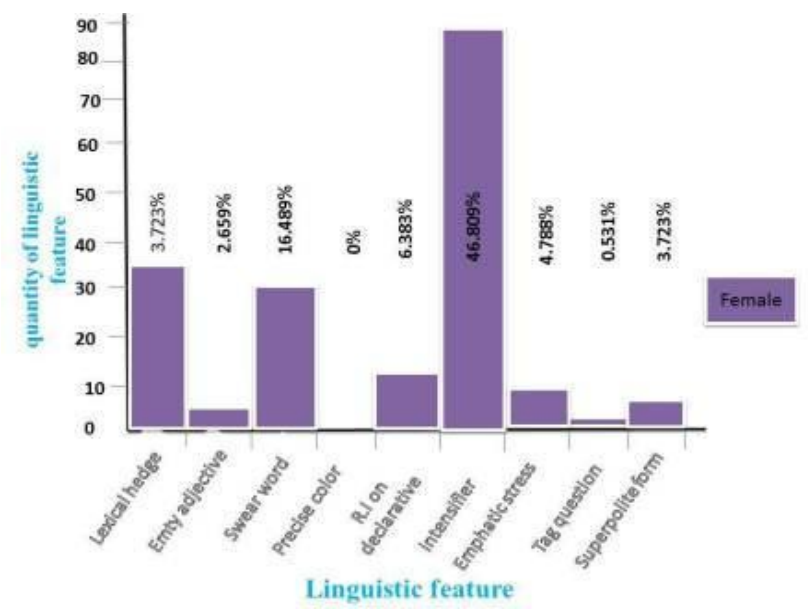

Diagram 2.2 Representative of the Frequency of Female Linguistic Feature

From the diagram above female characters did not use the precise color term in her speaking, a linguistic feature which is dominantly used by female characters was an intensifier. It was indicated that female was more unconfident and powerless in the society rather than male main characters and female was in the subordinate position. It showed that female was more polite than male because they tend to use these feature to avoid friction during speaking.

From the two tables above, it can be compared the frequency of linguistic feature between male and female characters of Pride and Prejudice novel below:

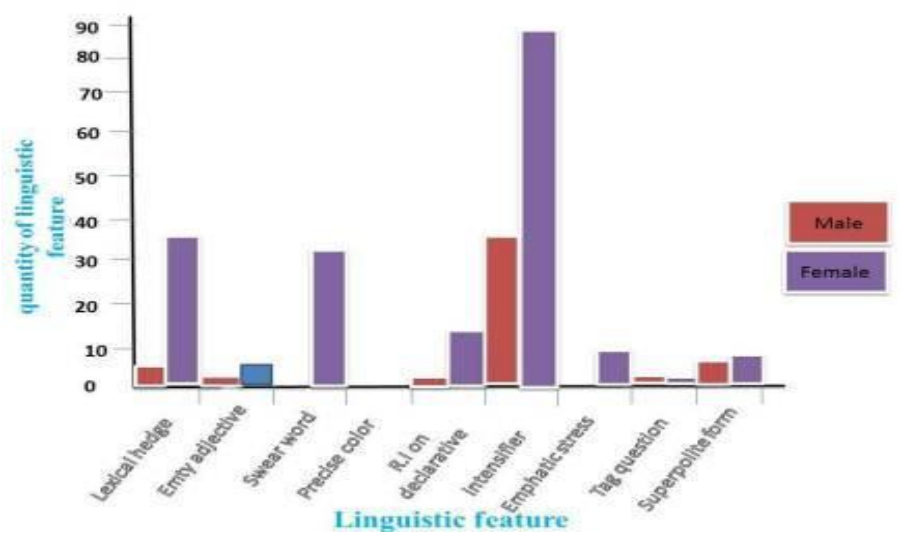

Diagram 4.3 Representative of the Frequency of Male and Female Linguistic Therefore from the representation of diagrams above, it can be concluded that the most linguistic feature which is dominantly used by male and female characters was 
an intensifier.

\section{The implication of this research in teaching speaking especially on complimenting and interrupting expression}

Speaking according to Oxford Learner's Pocket Dictionary derived from the word "speak" means "talk to somebody about something; use your voice to say something; to express your opinion. Speaking is how to pull out or express an opinion, the words we want to say. Spoken language not only asks people to speak but also asks the speaker to engage the listener in the conversation and make the conversation live. Speaking has gained primacy of status in language teaching and learning. Teaching speaking is activities which are purposed to make students can speak in a foreign language accurately, communicatively and bring the elements of speaking. In teaching speaking especially functional expression, a teacher should teach the students by using a good language so that the students accustomed to using it. Therefore, the students can use an expression in a different stage of interaction, and they know what expression they have to use appropriately.

Furthermore, in recent research the researcher explained the implication of this research in teaching speaking especially complimenting and interrupting expression as functional speaking below:

\section{a. Compliment}

A compliment is an expression that used to express approval to things, and the main purpose of compliment is to show that you like some aspects of other person's appearance, belongings, or work. Then, some people use a compliment to "butter up" somebody or to flatter in order to increase goodwill.

There are three ways to give a compliment: by saying something nice about the object, by asking how the person made it or where it was bought (but not how much it cost), or by asking for another look or another serving, if it is food. The examples of complement expression such as:

(1) I think your hair is very nice.

(2) How good your car!

(3) Pretty good. (see Bruce Tillit, 1985:66)

Above are the examples of complement expression that use good language. The example (1) used a phrase I think, which indicated that someone intends to strengthen his or her assertion. Then, the example (2) someone gives a compliment to others by using emphatic stress which also intends to strengthen his or her assertion, the last is the example (3) it uses woman's language called empty adjective which intends to convey an emotional reaction for showing someone admiration to things. In short, a compliment is an expression that usually used to give appreciation to someone when he noticed something new.

The result of this research was there are many differences between male and female in using the linguistic feature, then, from those differences, it can be concluded that 
female was more polite than male. Linguistic features which are considered to be polite in teaching complimenting expression are super polite form. Here are some examples of giving compliments:

(1) I would like to compliment you that your performance is really good tonight.

(2) Your car is very good.

Those are examples of giving compliment by using good features, example (1) it uses superpolite form feature, and it is used to give a compliment to one politely. Then, the example (2) it also uses a linguistic feature called intensifier 'very' which is used to strengthen someone's compliment.

Furthermore, a linguistic feature which is considered to be impolite during giving compliment is rising intonation on declarative, here is the example:

(1) You are pretty?

That is the example of giving a compliment which is considered to be impolite because it can offend one's feeling. This sentence has two meanings; they are: someone is truly beautiful, or the speaker means that someone is not beautiful (the speaker hesitates her beauty).

Therefore, the implication of this research in teaching complimenting expression is a teacher may give the students assignments which related to expression material, and the students should determine which linguistic features that considered to be polite language. Consequently, students can use good language after learning about it. In this case, students will be able to show what and how they are feeling to whom they are talking appropriately.

b. Interrupting

Interrupting is stop a person from speaking for short period by something you say or do, or stop something from happening for a short period. This is sometimes difficult to do in another culture, where the gesture or ways of speaking are very different from your own. In a conversation, it is impolite to interrupt in the middle of a sentence; you should wait until the sentence has been completed. This called "turntaking" and helped minimize the confusion that comes from not listening to what the other person is saying. Normally we do not interrupt someone who just met since it is considered impolite. However, it sometimes happens on occasion when someone is helpful. (see Bruce Tillit, 1985:78)

The phrases of interrupting expression such as:

(1) I am sorry to interrupt you, but....

(2) I would like to say something if you do not mind.

So, from the phrases above, it can be inferred that linguistic features which are considered to be a polite feature to express interrupting expression are super polite form, and avoidance strong swear word. Above are phrases which are considered to be polite form. Here is the example of interrupt someone:

Carrolate: "Hi Laura, what are you doing?" 
Laura: "I am writing a short story, I always

make a story every(.....)."

Carrolate: "Do you mind if I say something?"

Laura: "Ohh yes, please."

Above is a conversation between Carrolate and Laura, the bold sentence above is an example of the interrupt, someone, politely.

Here is the example of interrupt someone impolitely:

Mr. Boy: "Do you know where is my bag?"

Mrs. Saron: "No, I do not know, but...."

Mr. Boy: "Stop, why you don't keep my bag well, shit."

Above is the example of interrupting someone impolitely because it uses the inappropriate phrase. He also uses strong swear word like "shit." This sentence may be broken someone's heart, and it should be avoided.

The implication of this research in teaching speaking mainly interrupting expression is a teacher may give assignments about interrupting expression, and the students should determine which Phares which considered to be a polite expression. After learning about it, the students will expose some expressions which considered to be polite to express interrupting expression like I am sorry, I would like and something else. Consequently, it will not emerge a problem during the conversation. Therefore, it can build an effective communication inter and across gender.

\section{Discussion}

The results obtained from this research revealed that male and female characters differ in their number of use of linguistic features. Female characters are stated use more lexical hedge, avoidance of strong swear word, rising intonation on declarative, empty adjective, intensifier, emphatic stress and super polite form than male do. Therefore, this result is in line with Lakoff's theory.

Analyzing the conversation of male and female main characters in Pride and Prejudice novel, it is discovered that female used more polite linguistic forms than a male character. It was indicated by linguistic feature mainly superpolite form which is used to express euphemism in the speech of female characters are higher than male. By using intensifier, it showed that female characters tend to avoid some frictions when they were talking. Understanding these differences in speech will help male and female to understand each other better and develop an effective communication across gender.

Furthermore, it may have an implication in teaching speaking especially complimenting and interrupting expression as functional expression. The implications are the students will expose expressions appropriately, and they also know how to interrupt someone politely by choosing a good language. 


\section{Conclusion}

From all the data analysis about gender differences of male and female speech in Pride and Prejudice novel and its implication in teaching speaking, it can be concluded that: first, female characters used more linguistic features listed by Lakoff than male do. Therefore, female characters are considered use more polite language because they tend to avoid strong swear word, super polite form and express their uncertainty which can avoid some friction during held a conversation. So, this finding is in line with Lakoff's theory. Second, the linguistic feature which is dominantly used by male and female is an intensifier. The intensifier is used to strengthen one's assertion for example. This scenery is very beautiful. Third, this research has implication in teaching speaking especially complimenting and interrupting expression. A linguistic feature which is considered to be a polite feature to give a compliment is super polite form, while linguistic features which are considered to be a polite feature to express interrupting expression are super polite form and avoidance of strong swear word. Then, a linguistic feature which is considered to be an impolite feature to express complimenting expression is rising intonation on declarative. So, the implications were the student needs to exposed expressions of complimenting and interrupting appropriately. Consequently, it will build effective communication. 


\section{References}

Afrizal. (2014). Metode Penelitian Kualitatif. Jakarta: Rajawali Pers

Arikunto, Suharsimi. (2002). Metodologi penelitian. Jakarta: Rineka Cipta

Austen, Jane. Pride and Prejudice, a novel from http://www.gutenberg.org/etext/1342 1813, retrived October 21, (2016).

Fakih, Mansour. (1996). Analisis Gender \& Trasformasi Sosial. Yogyakarta: Pustaka Pelajar

Holmes, Janet. (2001). An Introduction to Sociolinguistics. ( $2^{\text {nd }}$ Ed). London: Longmen

Hornby. (2005). Oxford Learner's Pocket Dictionary, Third Edition. New York: Oxford University Press

Kenthjono, Djoko. (2003). Dasar-Dasar Linguistik Umum. Jakarta: Universitas Indonesia

Lakoff, Robin. (1975). Language and Woman's Place. New York: Harper\&Row Publisher

Masoomeh Hanafiyeh and Akbar Afghari, Islamic Azad University, research from http://www.cibtech.org/sp.ed/jls/2014/04/JLS-132-S4-147-MASOOMEHGENDER-WOMEN (2014), retrieved: October 21, 2016.

Sanjaya, Wina. (2013). Penelitian Pendidikan: Jenis, Metode dan Prosedur. Jakarta: Kencana

Tillit, Bruce. (1985). Speaking Naturally: Communication Skill American English. New York: Cambridge University Press

https://en.wikipedia.org/wiki/Pride_and_Prejudice retrived: January 05, (2017). 